\title{
OS SENTIDOS DO CONSUMO
}

\author{
Por Isleide Arruda Fontenelle \\ Professora da FGV-EAESP \\ E-mail: isleide@fgvsp.br
}

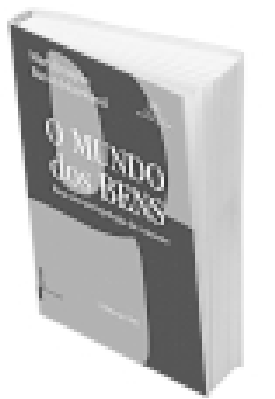

\section{O MUNDO DOS BENS: PARA UMA ANTROPOLOGIA DO CONSUMO}

De Mary Douglas e Baron Isherwood

Rio de Janeiro: Editora UFRJ, 2004. 306 p.

0 pano de fundo social presente no livro da antropóloga M ary Douglas e do economista Baron Isherwood tem recrudescido nos últimos anos: a crescente onda de protestos contra a sociedade de consumo. Os autores propõem que, antes de partirmos para uma condenação moral ao ato de consumo, nos perguntemos sobre a questão fundamental que esse ato nos coloca: por que os consumidores compram bens? Para responder a tal questão, os autores convocam um diálogo interdisciplinar entre a Antropologia e a Economia.

A Antropologia é contemplada em seu método e em seus princípios teóricos básicos, quando os autores propõem pensarmos o consumo como um elemento do processo so- cial. Com isso, decorre o subtítulo do livro, "Para uma an tropologia do consumo", na medida em que a teoria do consumo teria que ser vista como uma teoria da cultura e da vida social, uma espécie de gramática que permitiria ler uma cultura.

$A$ Economia é revisitada a partir da crítica à teoria da demanda, que, apesar de estar no centro do nascimento da economia como disciplina, teria sido incapaz de responder à questão que não Ihe deveria escapar: por que as pessoas querem bens? A teoria do consumo conspícuo, proposta por Thorsten Veblen, não escapa da crítica aos limites explicadores da teoria econômica para o fato de consumirmos, pois, embora Veblen tenha avançado sobre a teoria utilitária para sustentar que 0 ato de consumo teria uma significação social, teria sido responsável por uma idéia generalizada e simplista da emulação.

O diálogo entre os campos da Antropologia e da Economia se torna fecundo no momento em que os autores propõem uma definição antropológica do consumo usando dois postulados essenciais ao pensamento econômico: primeiro, o consumo não é imposto; segundo, o consumo começa onde termina o mercado. Com base nesses dois postulados, os autores definem o consumo como "um uso de posses materiais que está além do comércio e é livre dentro da lei" (p.102).

A busca de um diálogo que permita a ponte entre esses dois campos é uma constante ao longo do de- 
senvolvimento do livro. A obra se estrutura em duas grandes partes. A primeira analisa por que queremos os bens, por que não os queremos (e preferimos poupar), como os usamos, como seu uso nos inclui ou exclui e fala sobre a tecnologia e as periodicidades do consumo. A segunda parte articula esferas econômicas separadas na etnografia, faz comparações internacionais, diferencia classes de consumo e define a noção de controle do valor da perspectiva do uso do tempo.

$\mathrm{Na}$ primeira parte, os autores fazem uma varredura crítica por todas as teorias econômicas que, de alguma forma, estariam relacionadas ao consumo e ao não-consumo, além de questionarem al gumas idéias que se infil traram na análise econômica acerca das necessidades humanas por bens, como a teoria higiênica ou materialista e a teoria das necessidades por inveja. A análise weberiana sobre a ética protestante e o espírito do capitalismo também é questionada. Para os autores, Weber teria tomado o espírito como dado, quando o objetivo maior deveria ter sido o de descobrir como esse "espírito de época" foi gerado.

Para avançar na proposta de "repensar o consumo", os autores recorrem à etnografia para anal isar a significação que a posse dos bens carrega e o seu valor cultural como comunicadores. Dessa forma, o consumo dos bens é tomado como parte de um sistema de comunicação, como um ato onde se dá visibilidade e estabilidade às categorias da cultura. Em suas próprias palavras, "a função essencial do consumo é sua capacidade de dar sentido" (p.108).

Visando elucidar tal perspectiva, os autores fizeram comparações entre o que é chamado de "espaço moderno" - nossas casas - e outras casas, em épocas remotas e lugares di- tos exóticos, onde mercados e mercadorias ainda seriam produtos escassos. Práticas de marcação social e estratégias de inclusão também são comparadas em épocas distintas, a fim de mostrarem que os bens não são meras mensagens, mas algo que constitui o próprio sistema.

Dessa forma, os bens são pensados como o hardware e o software de um sistema de informação "cuja principal preocupação é monitorar seu próprio desempenho" (p.120). Se os bens são pensados em termos de acesso à informação, então o consumo seria um campo em que a exclusão pode ser aplicada, pois há aqueles que controlam seu acesso. Os autores vão concluir que ao final o consumo relaciona-se com o poder, e nenhuma teoria séria do consumo poderia evitar a responsabilidade da crítica social.

Tal assertiva nos remete à segunda parte do livro, cuja proposta é oferecer uma abordagem diferente das relações entre consumo e integração social e, em última instância, entre consumo e pobreza. Nessa perspectiva, os autores desenvolvem uma maneira de medir o envolvimento social comparando padrões de consumo, e afirmam esperar que essa medida revele mais sobre a desigual dade social do que as medidas de distribuição de renda.

Tomando a idéia do controle do acesso aos bens como o fio condutor dos padrões de consumo, os autores concluem que o modo de erigir barreiras pelos que controlam as entradas impede que muitos participem das trocas. E a questão da proteção das fronteiras é algo que poria em jogo toda a questão do controle social. Afirmam que, no instante em que tal proposição for apreciada por inteiro, a teoria do consumo poderá ser reintegrada à análise da economia.
Por isso, os autores nos fazem compreender que não haveria sentido em falar de "irracionalidade do consumidor", como se fossem marionetes presas nas artimanhas da propaganda ou consumidores que competem invejosamente. Adicionalmente, o risco da exclusão inibiria uma interpretação puramente racional desse universo do consumo, já que os consumidores teriam uma necessidade mais direta de se relacionar com outros consumidores e, por conseguinte, de consumirem bens. Diante disso, os autores propõem que os bens sejam tomados como "fios de um véu que disfarça as relações sociais que cobre" (p. 275). Nesta abordagem, os bens marcam apenas os padrões. M as o que interessa, fundamentalmente, é o "fluxo de trocas" para o qual nos dirigem.

Tal proposta tem como contexto o grande desafio que o livro se propôs: reconhecer o consumo como "parte integrante do mesmo sistema social que explica a disposição para o trabalho" (p. 26). Em outras palavras, articular as esferas econômicas da produção e do consumo. Como os próprios autores assumem, esse desafio não foi de todo cumprido, em parte por fal ta de um modelo econômico em que se mesclem os modelos de produção e de consumo. Mas, sem dúvida, os autores avançaram muito neste desafio e deixaram uma tarefa imensa para todos que se interessam em pensar o consumo na contemporaneidade.

Mesmo publicada no Brasil 25 anos após sua primeira edição na Inglaterra, a obra não é datada em suas reflexões. Embora o consumo tenha se acelerado e sua tecnologia se alterado neste último quarto de século, uma das principais questões postas pelos autores - por que consumimos - ainda continua a nos inquietar. 